\title{
GRAVITY SURVEY AND STRUCTURE OF THE FORESTIER PENINSULA, SOUTHERN TASMANIA
}

\author{
by David Leaman
}

(with 13 text-figures)

Leaman, D.E.., 1997 (31:viii): Gravity survey and structure of the Forestier Peninsula, southern Tasmania. Pap. Proc. R. Soc. Tasm. 131: 77-84. https://doi.org/10.26749/rstpp.131.77 ISSN 0080-4703. Leaman Geophysics, GPO Box 320C, Hobart, Tasmania, Australia 7001 and Geology Department, University of Tasmania, GPO Box 252-79, Hobart, Tasmania, Australia 7001.

A gravity survey coupled with review of regional mapping has shown that the widespread exposure of Jurassic dolerite across the Forestier Peninsula is due largely to repetition of a thick sheet by gently ramped Tertiary fault-blocks. Feeders for the sheet appear to be located near the centre of the peninsula and to be related to concealed pre-Permian structures, such as granitoid margins. At least two major fault zones were eroded during the mid Tertiary and these, as well as the peninsula ties to mainland 'Tasmania and the Tasman Peninsula, now consist of Tertiary materials covered by Recent sands. The western edge of the East Tasmanian batholith extends approximately northsouth beneath the centre of the peninsula.

Keywords: Tasmania, dolerite, structure, Forestier Peninsula, faulting, intrusion.

\section{INTRODUCTION}

This paper documents the first semi-regional gravity survey and structural interpretation of the Forestier Peninsula (fig. 1).

Previous geological work has been largely limited to regional mapping of the main body of the peninsula (Gulline 1982, 1984), sketch mapping of the Eaglehawk Neck area (Banks et al. 1989) and some discussion of aspects of the dolerite intrusions along the eastern coastline (Leaman $1978,1997)$. All previous geological maps of the area have been found to be flawed, mainly due to problems of windblown sand cover and talus deposits, coupled with rapid reconnaissance methods. A revision is offered in this paper.

Only two significant large-scale gravity surveys have included the peninsulas of southeastern Tasmania; the road-based regional survey of Johnson (1972) and the widely spaced helicopter survey of Zadoroznyj (1975). Neither survey was able to define any local structures or adequately define regional character, although the Tasmanian data base has depended on such data in this area (e.g. Leaman et al. 1980, Leaman \& Richardson 1989). The regional data previously available were supplemented by a single detailed traverse near Dunalley (Leaman 1973). The survey discussed here provides a regular and widely distributed network which, when coupled with a refined geological base map, allows comprehensive structural analysis.

Structural interpretation has been focussed upon definition of regional features; fault blocks, fault patterns, dolerice intrusions, Tertiary basins, basement depth (subPermian rocks) and the location of the margin of underlying granitoids.

\section{GEOLOGY}

The geology of the peninsula was reviewed and inspected while observing gravity traverses. The principal aim, originally, was to note additional dips in sedimentary rocks, to record textural variations in the dolerite and to inspect

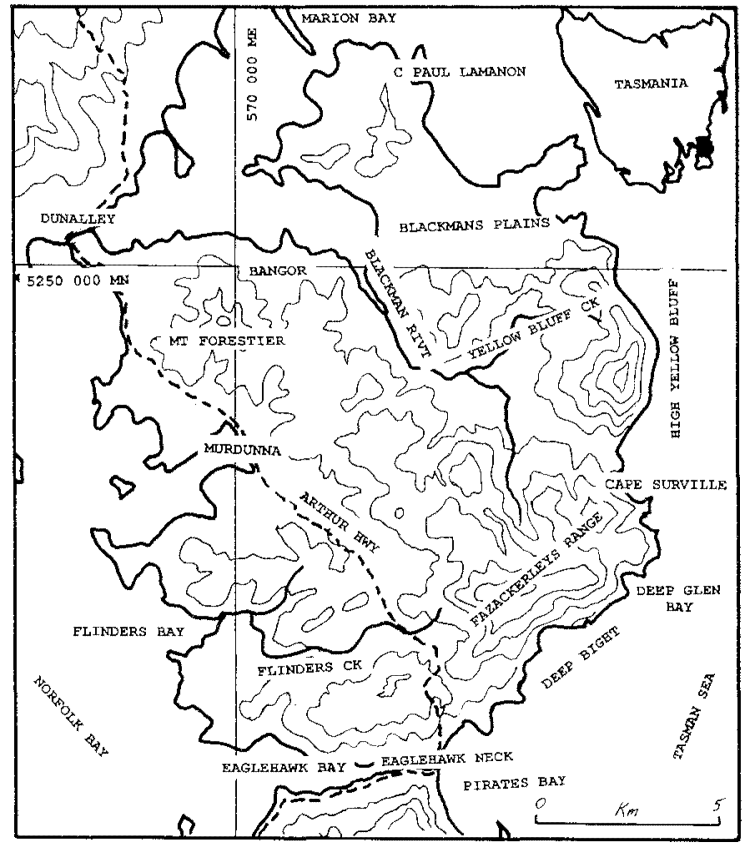

FIG. I - Locality map for the Forestier Peninsula, southern Tasmania.

intrusive margins or contacts which might assist appraisal of the form of the intrusions. The widespread nature of the traverses and the availability of new walking routes, however, showed that some areas had not been traversed for previous maps and that many revisions were necessary. This paper includes a revised version of the regional map of Gulline (1982), based on such new traverses.

A detailed stratigraphy of the area has been provided by Gulline (1984), Gulline \& Clarke (1984) and. Clarke (1989). This paper considers only those parrs of the sequence where new information offers some clarification or variation.

The dominant rock in the region is Jurassic dolerite, which has been intruded, in the form of thick sheets or 
wide dykes, into a succession of essentially flat-lying Permian marine rocks and Triassic continental rocks. The terrain is generally fairly rounded, with moderate relief generally decreasing to low relief in the west, and cliffs only occur along the coastal section south of Marion Bay. The Permian rocks were deposited on a basement composed of Devonian granitoids and (?) Ordovician-Devonian slates, phyllites and sandstones of the Mathinna Beds (Gulline \& Clarke 1984). Considerable relief, and consequent variation in thickness of the Permian succession, may exist on the basement surface. Banks et al. (1989) noted that up to $300 \mathrm{~m}$ of relief may exist in the region between Eaglehawk Neck and Deep Glen Bluff. Only the upper parts of the Permian succession are readily accessible; near Cape Surville, Deep Glen Bay and northeastern Bangor, near Cape Paul Lamanon. The lower parts of the Triassic succession are well exposed in the cliffs of High Yellow Bluff but are virtually inaccessible. Triassic exposures elsewhere are very poor and limited.

Significant changes in the regional map by Gulline (1982) were required in the region of Yellow Bluff Creek, Mt Forestier, Macgregor Peak and Machins Hill-Flinders Bay. A large tract of Triassic rocks had been omitted near Yellow Bluff Creek, and the contacts east of Mt Reynolds were shown to be irregular and not a simple faulted boundary. Dolerite talus blankets large parts of the peninsula east of the Arthur Highway, and the material may be mistaken for in situ dolerite. The northern and western slopes of Macgregor Peak are draped with this material, and some also occurs west of High Yellow Bluff and around $\mathrm{Mt}$ Forestier. Deposits near Mt Forestier tend to be thin, less than 1-2 m thick, but occur on a bedrock of both dolerite and Triassic rocks and conceal important boundaries. One of the best exposures of talus may be seen in a road cutting near the old coal mine lease at $567900 \mathrm{E}, 5247300 \mathrm{~N}$, where a mixture of angular and semi-rounded dolerite pieces directly overlies thin coals, mudstones and quartz sandstones.

Gulline (1982) did not subdivide the Permian sequence south of Cape Surville, but a primary division is shown in the revised map (fig. 2). This is based on limited exposures and access from the north side of Fazackerleys Range and Deep Glen Creek and is generally consistent with Gulline \& Clarke (1984) and Banks et al. (1989). The calcareous units of the central section are not well exposed away from the precipitous cliffs of Deep Bight and the lower slopes of Fazackerleys Range. The subdivision is based on the faunal zonations of Clarke (1989).

Construction of the highway bypass on Hawks Hill has revealed that the boundary between Permian rocks exposed along the coast - near the Tessellated Pavement and Clydes Island (see Banks et al. 1989) - and the dolerite of Hawks Hill and Cashs Lookout is a compound, faulted intrusion. The boundary is obscured by sand near Eaglehawk Neck, but road cuts and two small quarries show that coarse-grained dolerite abuts Permian rocks in the lower part of the hill and Triassic rocks near the hill crest. The boundary is, however, intruded by a narrow dyke $(5-6 \mathrm{~m}$ wide) in most places, although this is offset into the Permian rocks near the road crest. Other, narrower dykes may be found within the main body of dolerite. The larger dyke can be traced as far as Macgregor Link Road (at $575400 \mathrm{E}$, $5241700 \mathrm{~N}$ ). Extensive metamorphic effects may be noted within the upper Permian section on Hawks Hill, which are not consistent with small dykes. The separation of

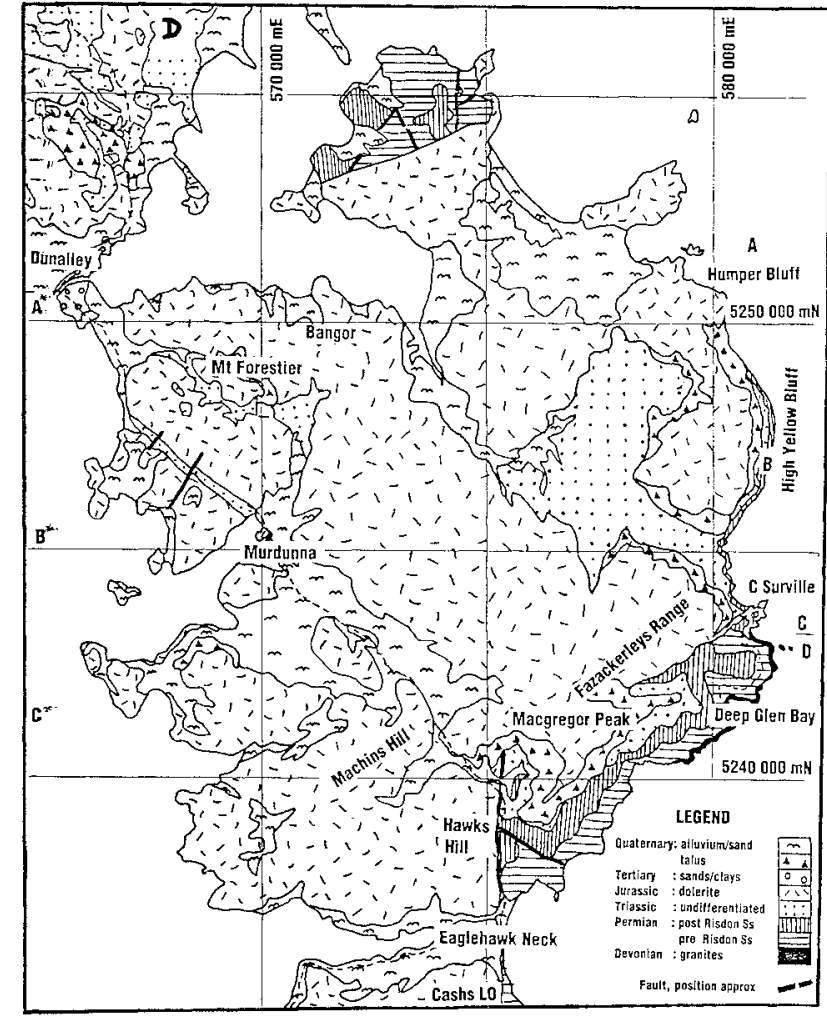

FIG. 2 - Simplified geology of the Forestier Peninsula. Regional section lines modelled are labelled $A A^{*}, B B^{*}, C C^{*}$, $D D$. The asterisk indicates that the origin is off the map (coordinates given in text).

The geological base map is derived from Gulline (1982); all revisions are included, as discussed in the text.

dykes and main contact on the upper part of the hill shows that the main intrusion, which probably occupied a preexisting fault, was itself intruded, then faulted at least once during the intrusion sequence. It has been faulted again subsequently.

The Permian rocks adjacent to the dolerite dip very steeply west in the central part of Hawks Hill and strike $\mathrm{N}-\mathrm{S}$ consistent with the orientation of the main fault or intrusive boundary. Parts of the Cainozoic deposits in the eroded fault zone also dip steeply west.

The only other extreme examples of thermal metamorphism may be found at $566600 \mathrm{E}, 5246850 \mathrm{~N}$, where Triassic sandstones have been recrystallised and thermally jointed, and near Cape Paul Lamanon, where Permian rocks have also been deformed (Lewis 1924). The Triassic contact is not well exposed, due to sand cover, but the companion contact near $566750 \mathrm{E}, 5246120 \mathrm{~N}$ is generally steeply dipping but very irregular. The small portions of Triassic sequence preserved appear to be near the roof to the intrusion (note the interpreted form at $6 \mathrm{~km}$, in fig. 8). The alteration and folding near Cape Paul Lamanon is consistent with a significant change in the form of intrusion and perhaps faulting concomitant with the intrusion (see also Leaman 1997, Single Hill).

Much of the information about dolerite contacts on Hawks Hill above Eaglehawk Neck has been obscured by an irregular blanket of Tertiary and Recent materials. These were discovered when road excavations were begun for the new highway bypass, and cuttings failed. Cuttings halfway up Hawks Hill display a weathered profile on Permian 
rocks, possibly with remnants of a soil, overlain by a weathered boulder bed composed almost entirely of dolerite fragments and dolerite-derived clay. This unit is patchy but overlain by clays, sands and sandy clays (Tertiary?), or by more recent dolerite talus deposits. The more recent, presumed Pleistocene, deposits locally overlie the sandy clays. All materials are unstable and were saturated at the time of road construction. The deposits appear to have been preserved on a hillside shelf, or within a narrow channel, about $100 \mathrm{~m}$ above present sea level. The channel has been engraved along the fault-contact zone. Similar materials have been observed at about this level on the slopes along the southern side of Eaglehawk Bay.

Gulline (1982) mapped widespread sand deposits across the peninsula as Pleistocene-Recent in age and windblown in origin. While these conclusions may be generally valid, it should be noted that many such deposits contain a high clay content and may be remnants of Tertiary deposits. The colouring, composition and character of the presumed Tertiary deposits are consistent with materials found widely across southern Tasmania. No fossils have yet been found in these materials on the Forestier Peninsula. The new map (fig. 2) indicates the expanded extent of cover deposits, although not enough is yet known to discriminate properly Recent wind-blown sands and older Tertiary(?) sandy clay deposits.

Patterns in the regional dips recorded from Permian exposures suggest a major structural anomaly. In the northern part of the area south of Marion Bay (Bangor), dips are gentle and consistently to the west (up to $10^{\circ}$ ). Elsewhere, there is no regular pattern, and most rocks are virtually flatlying. Around High Yellow Bluff and north of Eaglehawk Neck, dips are subhorizontal and low-amplitude, longwavelength folds can be found. The dip patterns are not consistent with the extensional fault rotations which might be anticipated, as a reaction to rifting either in the Storm Bay or Tasman Sea regions. Dips are not systematic across the peninsula. A regular dip pattern could be expected, due to rifting or extension, or to regional uplift, which has produced the generally westerly dips across much of southern Tasmania. This structural style is only observed in northern Bangor. These observations suggest, since major uplift reaction from the Tasman Sea separation must have occurred, that isostatic recovery is virtually complete and that equilibrium has been restored, or that responses due to rifting in both east and west have cancelled. The latter possibility seems unlikely since the Storm Bay-Derwent rift axis was clearly active into mid Tertiary time and was clearly an order of magnitude less significant than the Tasman separation. The limited block rotations across the peninsula also imply that Tertiary faulting was relatively minor.

Few faults or intrusive margins exist, or can be mapped, on the peninsula. Several structures display an extended or compound history.

Faults in northern Bangor trend either NE-ENE or a little east or west of north. Faults north of Murdunna trend northeast and the large structure along the eastern side of Hawks Hill trends N-S. High-angle intrusive boundaries, such as those found on north Bangor and near Cape Surville, trend ENE or northeast whilst those faults east of $\mathrm{Mt}$ Forestier and Hawks Hill trend N-S. Other contacts, such as those berween Murdunna and Dunalley, trend NNW or northwest.
Many smaller faults between Cape Surville and High Yellow Bluff trend approximately E-W. Gross drainage lineaments and fracture patterns indicate a fundamental grain, which includes features which trend northwest and ENE. These orientations are generally consistent with the observations reported for the Tessellated Pavement at Eaglehawk Neck by Banks et al. (1989).

Review of the pavement fractures, however, suggests that reported values are either in error or were magnetically defined, since mean orientations are about $15^{\circ}$ and $85^{\circ}$ with a subset at about $355^{\circ}$ rather than the $330-335^{\circ}$ and $75^{\circ}$ reported. The new observations have been confirmed at the main pavement by Dr M.R. Banks (pers. comm.) with measured means of $13.5^{\circ}, 89^{\circ}$ and $1^{\circ}$ respectively. Some minor variations clearly exist within the pavement area, but the two new sets of measurements are concordant and accord with the regional trends more accurately than the published data. The fractures at the pavement display a complex interplay and are dextral (north-trending) and sinistral (east-urending) shears which are neither consistently nor regularly developed through the beds of the formation. Most of the pavement fractures develop upon exposure and weathering of the individual beds and only a small proportion can be considered penetrative or tectonic. There may be no simple relationship berween faults, intrusions or obvious joint sers.

\section{GRAVITY SURVEY}

The gravity survey has been undertaken as a new entity independent of the very limited older surveys, in order to remove any risk of dependence on uncertain positions or poor tie links. Most old (pre-1970) tie points cannot be found or occupied. The new survey has been directly linked to Hobart Base (6091.0160, observed gravity 980.44427, at the Engineering Building, University of Tasmania) via a chain of new ties. All intervals in the tie network were multiply observed and drift corrected, and all standard stations have been drift corrected. Elevations were determined barometrically, using the method of Leaman (1984), but many sites were observed either at mean or high-water mark or at survey spot heights. Differential GPS methods have not been used, due to non-availability and lack of secure lock on satellites in this densely forested area. Many elevation estimates are accurate within $0.5 \mathrm{~m}$, while others may contain local errors of up to $2 \mathrm{~m}$. These estimates mean that gravity reduction at a density of $2.67 \mathrm{~kg} / \mathrm{m}^{3}$ implies a possible error of up to $0.4 \mathrm{mgal}$ in the Bouguer Correction. A terrain correction has been applied to all stations and was calculated graphically to a radius of $22 \mathrm{~km}$. The correction exceeds $1 \mathrm{mgal}$ in several areas. Some coastal, cliff top stations may be undercompensated due to inadequacies in maps, uncertainties in precise position or inability to define fully terrain close to the observation position.

The likely RMS precision in the Bouguer anomaly, given all observational factors and corrections, is estimated to range between 0.2 and $0.5 \mathrm{mgal}$ and to be less than $0.3 \mathrm{mgal}$ for most stations. A compilation of the Bouguer anomalies is shown in figure 3. Comparison with older data sets has shown that the data of Leaman (1973) and of Zadoroznyj (1975) can be retained, but that most stations acquired by and for Cameron (1967) and Johnson (1972) have been removed from the data base. Undefinable base level shifts were recognised in loop groups, and the average deviation 
was 2-4 mgal depending on the particular loop inspected.

Observed Bouguer anomalies present little systematic character, although a distinct gradient bisects the peninsula. Lower values occur to the east. This is very anomalous behaviour, since values should increase as the continental margin is approached, and it implies that a regional mass of low density material occurs at shallow depth beneath the eastern half of the region.

The observed Bouguer anomalies are not particularly valuable, due to the effects of the continental margin, and these have been removed, using the method of Leaman $\&$ Richardson (1989) as updated to crustal model MANTLE91. This model is subject to further revision, and refinement will be possible once a detailed survey of the Tasman Peninsula, now in progress, is complete. Residual Bouguer anomalies, derived from the current model, are shown in figure 4 and are not likely to contain any major local distortions. Future changes in MANTLE91 will affect the regional evaluation of southeastern Tasmania.

The residuals retain the substantial W-E gradient, and this reflects gross changes in the upper crust; namely, the presence of a batholith under eastern Tasmania. Parts of the granite complex are exposed along the coast between Cape Surville and Deep Bight. Some major local variations are imposed on the regional gradient. The most important of these are the step effect which strikes $N-S$ across the centre of the peninsula and the sub-circular zone centred near eastern Bangor. Most other changes are minor and swamped by the effect of the underlying batholith, and few can be evaluated by inspection. The residual map defines medium to short-wavelength effects generated in the upper crust, with negligible longer wavelength contributions, due to crustal thickness variations at or near the continental margin. Interpretation of the residual anomalies can be undertaken on the assumption that the mantle model produces locally reliable relationships.

More detailed coverage in the Dunalley and Eaglehawk Neck areas is shown in figures 5 and 6 .

The Dunalley survey shows that a distinct negative response curls across the region, which can be directly correlated with exposures of Tertiary sedimentary rocks. The Dunalley canal is excavated within these, and it follows their thickest development.

The Eaglehawk Neck survey does not reveal a comparable negative effect in the region of the neck or tie-bar. A reduced negative response is present, but the entire character of the gravity field is dominated by the effect of the major dolerite-Permian boundary extending $\mathrm{N}-\mathrm{S}$ across the head of Eaglehawk Bay.

\section{INTERPRETATION}

Six sections have been assessed quantitatively in order to indicace structural style and relationships.

Evaluation has utilised two dimensional methods and a rigorous set of interpretation criteria as defined by Leaman (1994). Use of these criteria leads to realistic and feasible solutions and a denial of invalid solutions. The criteria cannot confirm that any feasible solution found is true, only that it is possible or likely. Rock properties used in calculation have been based on tables published by Leaman (1972) and Leaman \& Richardson (1981). Sections are located in figures 2,5 and 6 .

\section{AA: Bangor east-west (561000/5250000-581000/5251500) Figure 7}

This section, of very low relief near sea level, exemplifies many of the geological problems of much of the area and demonstrates the value of a combined geophysical-structural approach. Dolerite is exposed for most of the section, and the remainder is covered by water. Two small segments contain Tertiary materials (near Dunalley). There is no surface suggestion of the nature of structures present.

The model indicates that the dolerite, as a single sheet, was transgressively intruded within the Triassic part of the sequence, and that the whole region has been faulted with a systematic downthrow to the east resulting in westerly dips. This is consistent with a rifted continental margin. Foci for transgression occur at 12 and $17 \mathrm{~km}$ and, although the entire character of the intrusion cannot be discerned, it is possible that feeder dykes occur near these locations. In this part of the peninsula, the present gravity survey alone cannot resolve any feeders (if present), and no adequate magnetic data are available which might clarify the issue. Texcural variations observed in the exposed dolerite are, however, consistent with an interpretation involving feeders, and data elsewhere are adequate (section DD). The model assumes a uniform thickness of Permian rocks. While there is no reason to expect any major variation in the upper part of the sequence, variations in the lower part cannot be resolved, due to the similarity of granitoid and Permian densities. The model is not affected, with regard to dolerite or fault patterns, even if the Permian section is thinned eastward. The implied displacements and relationships between stratigraphic positions and intrusion transgressions suggests a largely Jurassic (pre or syn intrusion) history on most faults. Demonstrable Tertiary movements are generally of the order of $100 \mathrm{~m}$.

\section{BB: Dunbabin Point to High Yellow Bluff (561000/5245000-581000/5247000) Figure 8}

The general dominance of dolerite near the land surface is again evident. This section may be contrasted with that across Bangor. All faults downthrow to the west, not east, although similar patterns of transgression and thickening are evident within the intrusions. The difference in fault patterns is explained in figure 13 where it is shown that the effect is due to the particular shapes of fault blocks and some changes in trend, within the regional pattern. Faults can be traced or inferred between sections, and displacements are generally less than $150 \mathrm{~m}$. The exceptional structure is west of High Yellow Bluff. The difference in structural pattern (from AA) is consistent with the observed differences in dip patterns between northern Bangor and the region of High Yellow Bluff. The model does not include any large variation in thickness of Permian rocks due to the equivalent and combined effect of Permian rocks and granitoids at the eastern end of the section. The model does show, however, that were an additional dolerite to be present within the Permian sequence - and no such intrusion is known in the region south of Deep Glen Bluff - it would need to be present across the entire section. Further, given the present crustal model (MANTLE91), such a body cannor be inserted 


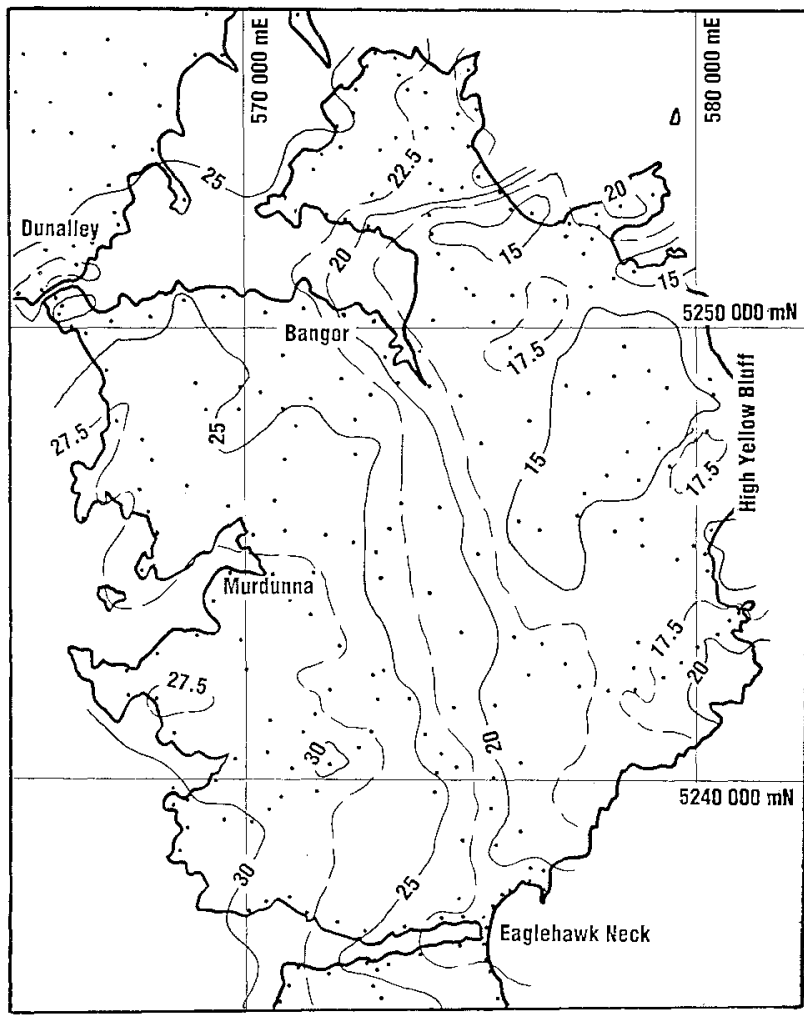

FIG. 3 -Observed Bouguer anomalies, Forestier Peninsula, based on a reduction density of $2.67 \mathrm{~kg} / \mathrm{m}^{3}$ and a datum base value of 980.44427. Station locations are shown as dots and all primary data are stored by Mineral Resources Tasmania. Contour interval $2.5 \mathrm{mgal}$.

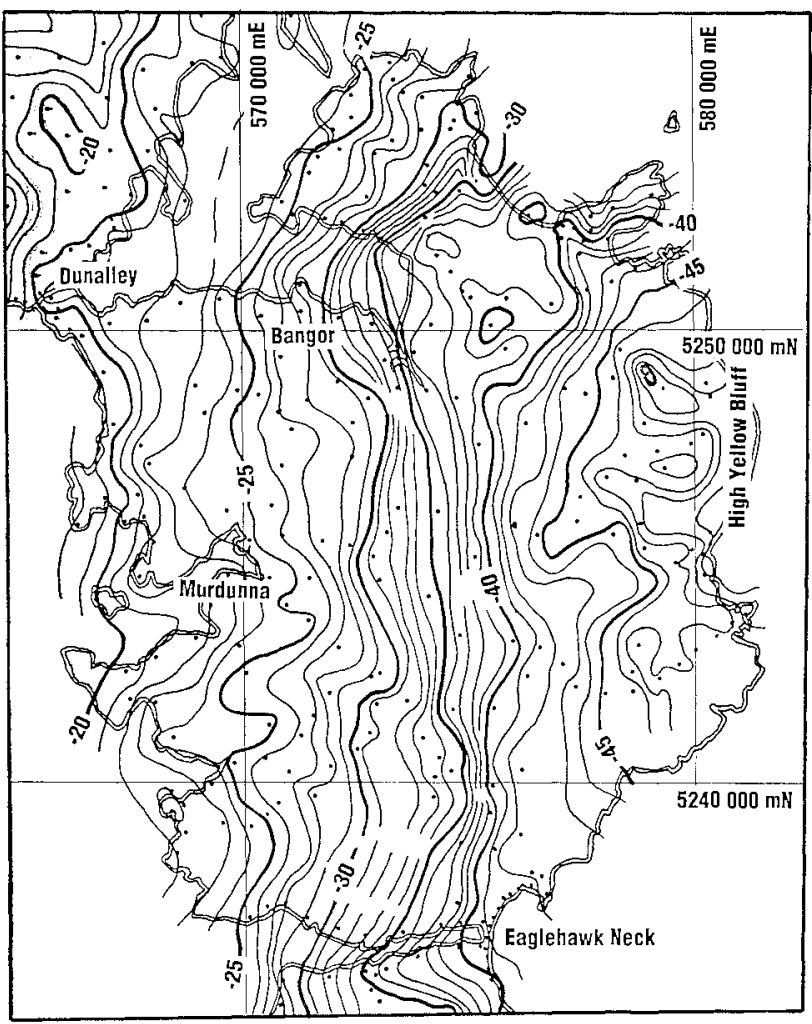

FIG. 4-Residual Bouguer anomalies, Forestier Peninsula, after compensation for a first order crust and ocean model. Contour interval 1 mgal.

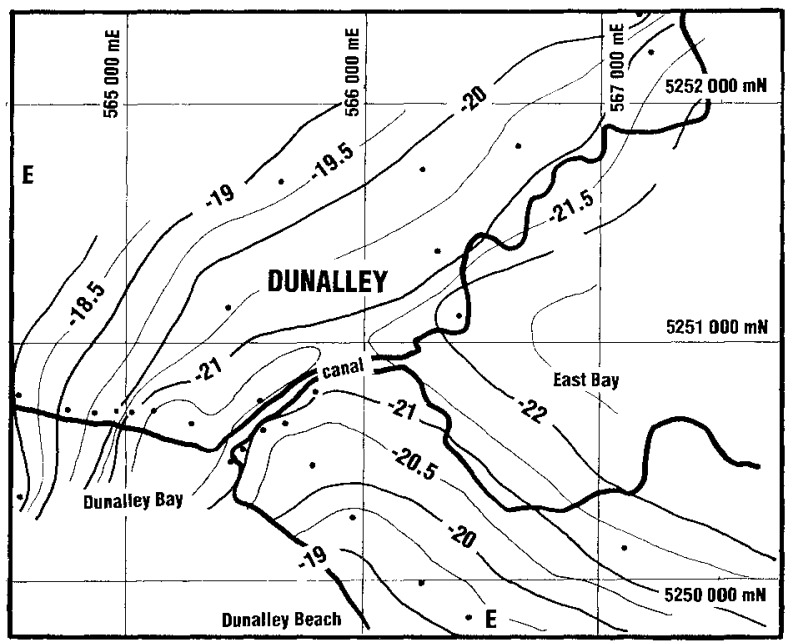

FIG. 5-Residual Bouguer anomalies, Dunalley area. Section line EE labelled. Contour interval $0.5 \mathrm{mgal}$.

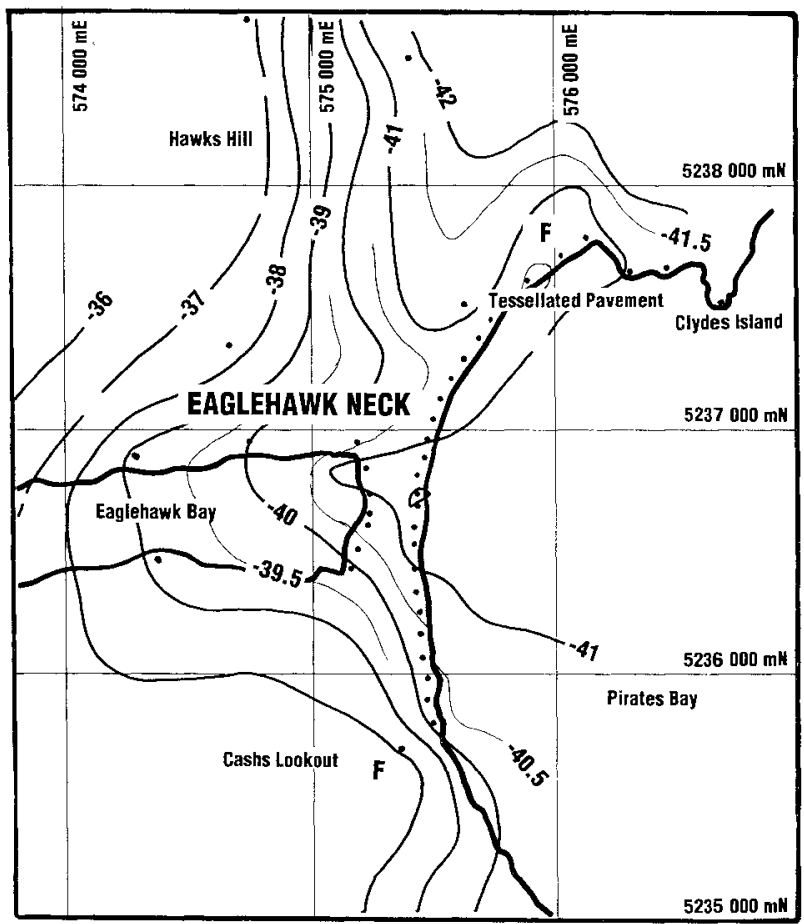

FIG. 6-Residual Bouguer anomalies, Eaglehawk Neck area. Section line FF labelled. Contour interval $0.5 \mathrm{mgal}$.

into the coastal block. These observations would suggest that the intrusion pattern within the peninsula is relacively simple. The eastern end of the model, however, does not fully explain the observed field. This may indicate deficiencies in the mantle model or, more likely, non-two-dimensional (2D) character, involving structures near sea level at the coast. The effect of the seawater may also not be accurately represented in $2 \mathrm{D}$ solutions. 


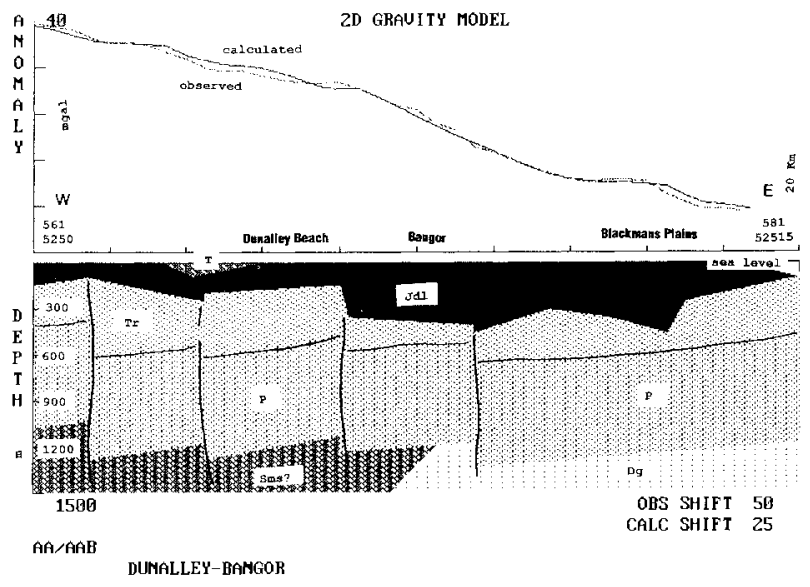

FIG. 7 - Structural model and interpretation for profile $A A$. Dunalley-Humper Bluff.

Note that the vertical scales provide value ranges $(40 \mathrm{mgal}$ and $1500 \mathrm{~m}$ ) for Bouguer anomalies and depth respectively. The section is $20 \mathrm{~km}$ long, and each horizontal axis distance mark has a separation of $2 \mathrm{~km}$. Observed and calculated shift values define the fit of the model, and consistent derivation of differentials provides a test of the veracity of the model (Leaman 1994). Faults are shown vertical since, in the absence of magnetic data, no dip can be assigned reliably.

\section{CC: Flinders to Cape Surville (562000/5241000-582000/5243000) Figure 9}

This section provides a different view of the dolerite distribution and shows how large parts of the southern half of the peninsula can carry significant talus deposits with concealed Triassic rocks - the sheet is almost eroded away in several places. A point of transgression has been defined at $12 \mathrm{~km}$ from the origin of the section and a small feeding centre is implied. Its position is consistent with similar thickening furcher north and appears to be associated with the underlying granite margin. The residual values, with inclusion of the coastal dolerite intrusion within the Devonian granitoids, show that no other dolerite is present and that the single intrusion seen penetrating the sub-Permian unconformity is the only major intrusion in the area (see also discussion BB). All faults clearly throw down to the west, in a pattern which is consistent with regional post-Jurassic extension and reactive coastal uplift, due to generation of the Tasman Sea.

\section{DD: Dunalley North to Cape Surville (568000/5257000-582000/5243000)} Figure 10

This section was modelled in order to provide a tieline check on other sections and to confirm the variations in dolerite thickness indicated. The model generally confirms the implications of other sections but illustrates the threedimensional nature of structures near Cape Surville and the inability of simple methods to define them (compare sections CC, DD). The model also shows that the distinct sub E-W gradient across northern Bangor is due to a dolerite feeder,

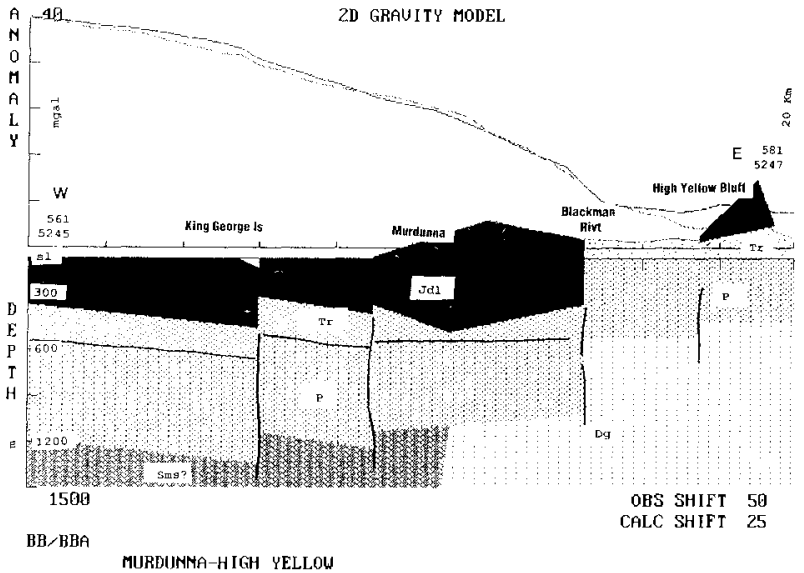

FIG. 8-Structural model and interpretation for profile BB. Murdunna-High Yellow Bluff.

Fitted anomaly range $40 \mathrm{mgal}$ (vertical axis) and horizontal length of $20 \mathrm{~km}$; subdivided into $2 \mathrm{~km}$ intervals. Note that the modelled section represents a subset of a much longer model in order to remove end effects.

which is located near the intersecrion of a large fault extending along Blackman Bay toward Marion Bay and the underlying granite margin.

The interpretation, with thickened dolerite at $9 \mathrm{~km}$, near Blackman Rivulet, provides a verification of the concept presented in line AA and suggests a complex threedimensional shape for this intrusion. The observed and calculated profiles would also match at Cape Surville, if the dolerite were removed from the model, and the precise positioning of the line, observed data locations, and shape of the cape were included. The model offers a first-order constraint on possibilities and shows that the intrusion exposed in Sisters Bay rises transgressively inland at the coast (also Leaman, 1997). No other intrusions can be present

\section{EE: Dunalley (Figure 5)}

This detailed model (fig. 11) is essentially an inset for the Bangor model (AA) described above. It offers a complete revision and solution for the canal zone and may be contrasted with the old estimate based only on a short coastal profile (Leaman 1973).

The model shows that the geometry of the Tertiary deposit, in which the canal has been excavated, is related to the underlying faulting and erosion along the structure. Up to $120 \mathrm{~m}$ of Tertiary materials are present. The orientation of the modelled fault is not accurately defined but the regional, rather than local, mass balances imply the general attitude shown. A feeder is implied northwest of Dunalley.

\section{FF: Eaglehawk Neck (Figure 6)}

A detailed model for a profile across the Neck is shown in figure 12.

The profile extends across the western side of the Neck, in order to sample the anomaly variation within the hillsides. 


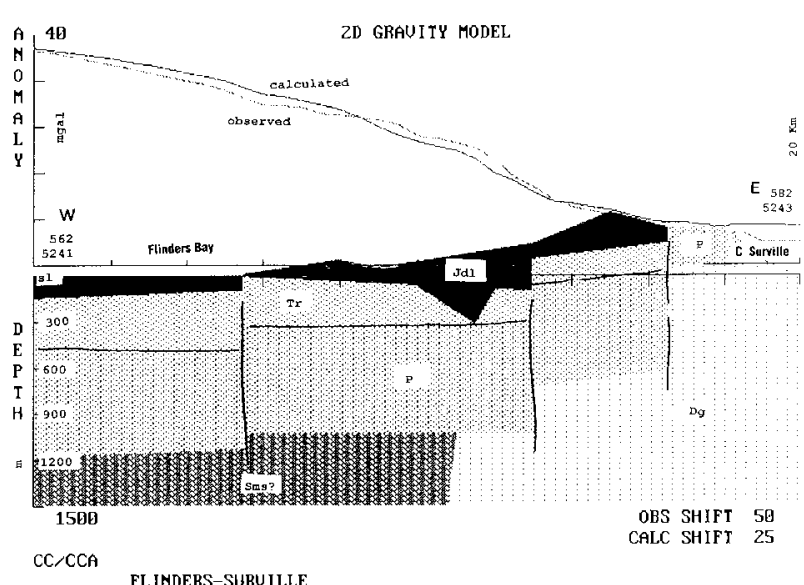

FIG. 9 - Structural model and interpretation for profile CC. Flinders Bay-Cape Surville.

Section length: $20 \mathrm{~km}$ marked in $2 \mathrm{~km}$ intervals.

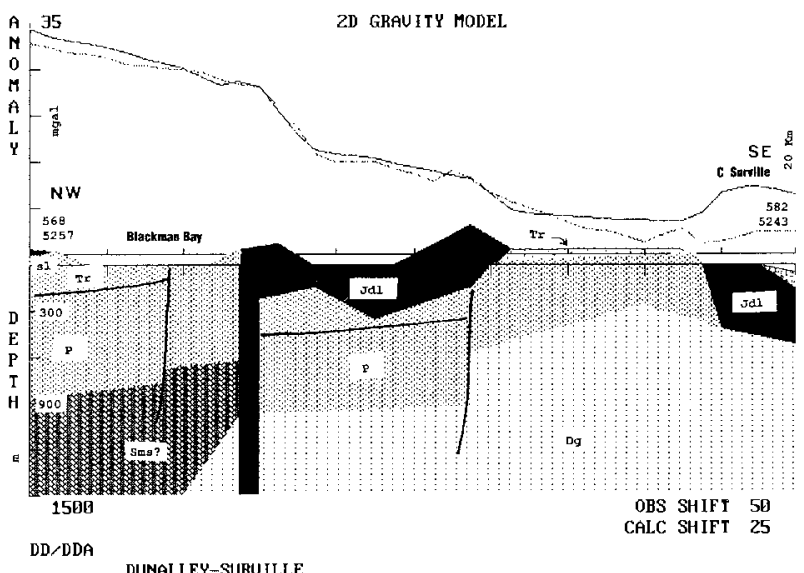

FIG. 10-Structural model and interpretation for profile DD. Dunalley north-Cape Surville.

Fitted anomaly range $35 \mathrm{mgal}$ (vertical axis) and horizontal length of $20 \mathrm{~km}$ marked at $2 \mathrm{~km}$ intervals. Note the consistent curve fitting differential of $25 \mathrm{mgal}$ for all regional models with a depth range of $1500 \mathrm{~m}$.

Inspection of Figure 6 shows that a simple or twodimensional representation of the field is not possible, due to the strong E-W gradient in the region of Hawks Hill and southern Pirates Bay. Although the model is influenced by some lateral effects, the solution does yield credible geological relationships and shows that up to $50 \mathrm{~m}$ of Tertiary sediment infilled an eroded channel, etched in a fault zone which extended westward along Eaglehawk Bay. The reduction in anomaly south of Eaglehawk Bay is due to a locally thick blanket of windblown sand (up to $30 \mathrm{~m}$ thick).

\section{CONCLUSIONS}

The models show that the area is extensively faulted al though post-intrusion displacements are generally less than $100 \mathrm{~m}$. Larger displacements are restricted to structures in the

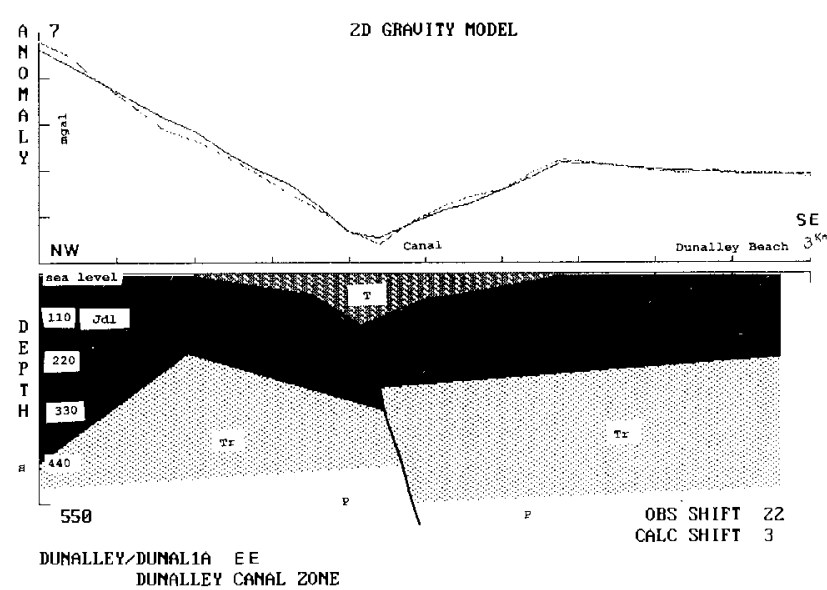

FIG. 11 - Structural model and interpretation for profile EE, Dunalley area.

The fitted anomaly range is $7 \mathrm{mgal}$ and the section length is $3 \mathrm{~km}$ marked at $300 \mathrm{~m}$ intervals. This model represents a refined version of part of line $A A$. A fault may be present at about $600 \mathrm{~m}$ from the origin and a dolerite feeder immediately west of the origin.

This local model requires different curve fitting parameters since the base of the Permian section, and basement detail, is not included in the model.

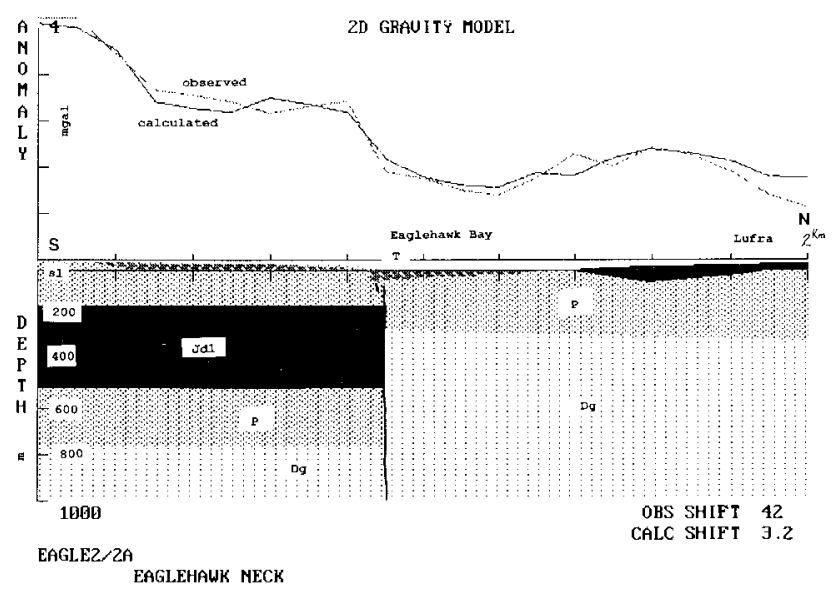

FIG. 12 - Structural model and interpretation for profile FF, Eaglehawk Neck area.

Anomaly range: $4 \mathrm{mgal}$, depth range: $1000 \mathrm{~m}$. Note the large fault which extends along Eaglehawk Bay and is now covered by Cainozoic deposits which form the tombolo.

eastern part of the peninsula. The pattern of displacements changes from north to south; mainly down to east in the north and down to west elsewhere. This effect results from the interplay of north and ENE-trending faults and the younger NNW-trending structures. Most post Jurassic faults strike a little west of north, although some large structures trend a little north of east. Many faults have clear relationships with dolerite intrusions, which suggest some concomitant origin but subsequent regional disruption. The largest, established feeder - north of Bangor - is associated with the intersection of several faults (fig. 13). All demonstrable Tertiary deposits are associated with faults which disrupt dolerite intrusions and were clearly eroded. This is most 


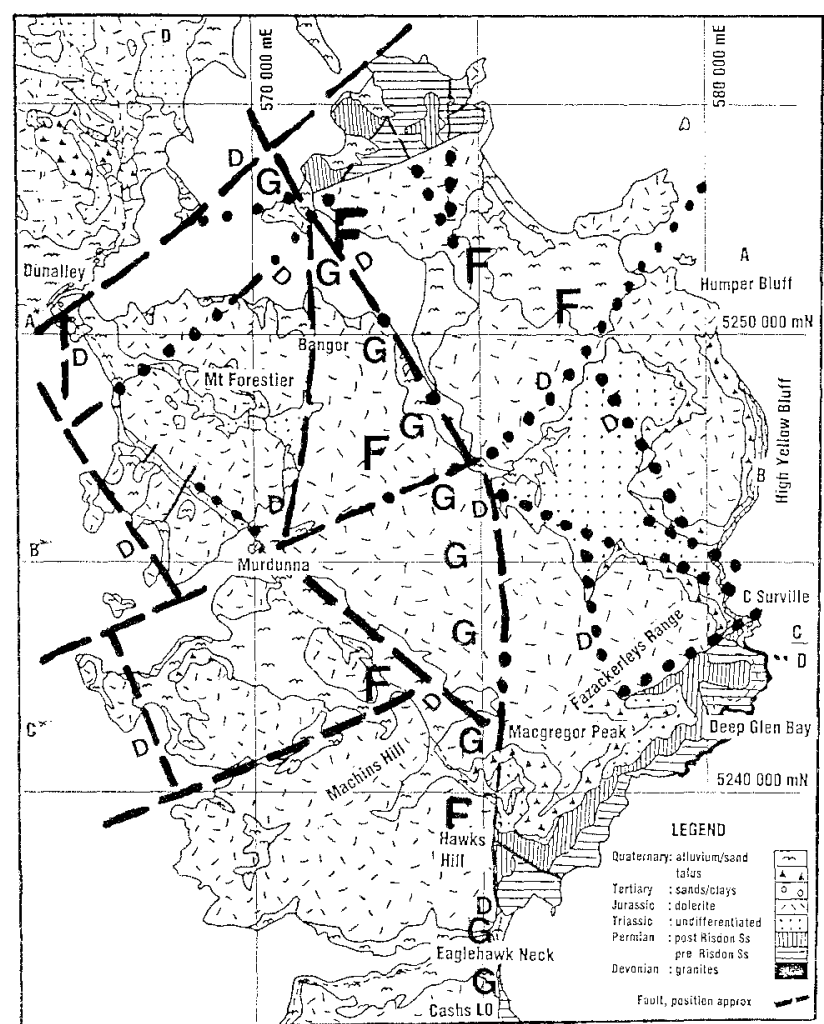

FIG. 13 - Structural summary. Interpreted faults are indicated by dots (Jurassic or pre-dolerite) or dashes (Jurassic and post-dolerite movement); downthrown side indicated. The approximate position of the underlying granite contact is marked $(G)$ and inferred feeder locations are labelled $(F)$. There is a close relationship between batholith margin and major faults; feeders are locally associated.

apparent at Dunalley but is also evident at Eaglehawk Neck and at Hawks Hill.

Dolerite feeders, demonstrated and inferred, are related to large faults in the region above the granite margin within the basement complex. The inferred feeder positions, based on texture, thickest development or deepest stratigraphic level, are aligned a little west of north, and most lie near the centre of the peninsula, from near $570000 /$ 5255000 , along the western side of Blackman Rivulet to Hawks Hill. The arc of feeding structures trends more N-S toward Eaglehawk Neck — as does the granite margin and the fault system above it. Textures and mineralogy of some of the dolerite on Cashs Lookout indicates that this feeding axis extends further south.

\section{ACKNOWLEDGEMENTS}

I am grateful for permission to use the gravity meter owned by the Geology Department of the University of Tasmania for this phase of survey and to Dr R.G. Richardson of Mineral Resources Tasmania for data base compilations. Field assistance was provided by Marcia Solomon. Mr \& Mrs Dunbabin of Bangor also granted permission to access their large and important property.

\section{REFERENCES}

Banks, M.R., Colhoun, E.A., Ford, R.J, \& Williams, E., 1989: A reconnaissance geology and geomorphology of Tasman Peninsula. In Smith, S.J. (Ed.):IS HISTORY ENOUGH? PAST, PRESENT AND FUTURE USE OF THE RESOURCES OF TASMAN PENINSULA. Royal Society of Tasmania, Hobart: 7-23.

Cameron, B.F., 1967: A regional gravity survey of eastern Tasmania. B.Sc. (Hons) thesis, Univ. Tasm., Hobart.

Clarke, M.J., 1989. Lower Parmeener Supergroup. In Burrett, C.F. \& Martin, E.L. (Eds): GEOLOGY AND MINERAL RESOURCES OF TASMANIA. Geol. Soc. Aust. Spec. Publ. 15: 293-309.

Gulline, A.B., 1982: Geol. Atlas 1:50 000 Ser. Zone 7, Sheet 83 (8412N). SORELL. Dep Mines Tasm.

Gulline, A.B., 1984: Geol. Atlas 1:50 000 Ser. Zone 7, Sheet 83 (8412N). SORELL. Explan. Rep. Geol. Surv. Tasm.

Gulline, A.B. \& Clarke, M.J., 1984: A diamond drill hole at Eaglehawk Neck, Tasman Peninsula. Unpubl. rep. Tasm. Dep. Mines 1984/76.

Johnson, B.D., 1972: Crustal structural studies in Tasmania. Unpubl. PhD thesis, Univ. Tasm., Hobart

LEAMAN, D.E., 1972: Gravity survey of the Hobart District. Bull. Geol. Surv. Tasm. 52.

Leaman, D.E., 1973. Gravity profile, Tertiary deposits, Dunalley. Tech. Rep. Dep. Mines Tasm. 16: 108-109.

LEaman, D.E., 1978: Some thoughts on dolerite intrusions with particular reference to marginal features. Rep. Geol. Surv. Tasm. 1978/30.

Leaman, D.E., 1984. Notes on microbarometer elevarion determinations. Explor. Geophys. 15: 53-69.

Leaman, D.E., 1994: Criteria for evaluation of potential field interpretations. First Break 12 (4): 181-191.

LEAMAN, D.E., 1997: Features of Jurassic dolerite intrusions at Cape Surville, Lynwood, Single Hill and Mount Nelson, Tasmania. Pap. Proc. R. Soc. Tasm. 131: 13-20.

LEAMAN, D.E. \& RiCHARDSON, R.G., 1981: Gravity survey of the East Coast Coalfields. Bull. Geol. Surv. Tasm. 60.

Leaman, D.E. \& Richardson, R.G., 1989: Production of a residual gravity field map for Tasmania and some implications. Explor. Geophys. 20: 181-184.

Leaman, D.E., Richardson, R.G. \& ShiRley, J.E., 1980: Tasmania - the gravicy field and its interpretation. Rep. Geol. Surv. Tasm. 1980/36.

LewIS, A.N., 1924: Note on a Cliff Section Near Cape Paul Lamanon. Pap. Proc. R. Soc. Tasm.: 45-50.

ZadorozNyJ, 1., 1975: Reconnaissance helicopter survey, New South Wales, Tasmania and South Australia 1973/4. Rec. Bur. Miner. Resour. Geol. \& Geophys. Aust. 1975/85.

(accepted 27 May 1997) 